\title{
Correction: Comparative oncology DNA sequencing of canine T cell lymphoma via human hotspot panel
}

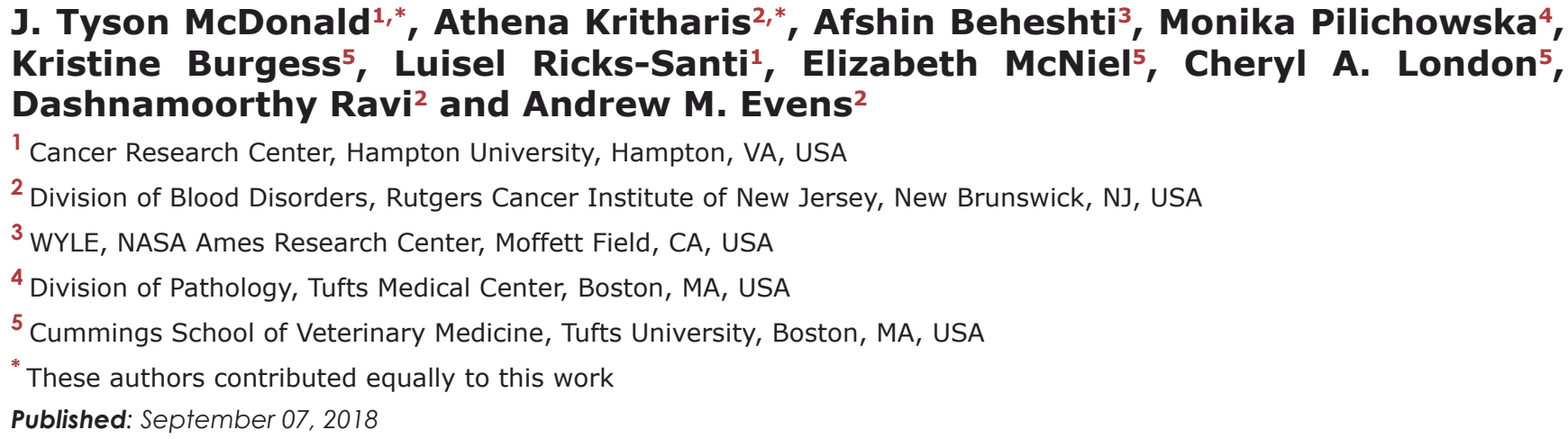
Kristine Burgess ${ }^{5}$, Luisel Ricks-Santi ${ }^{1}$, Elizabeth McNiel $^{5}$, Cheryl A. London ${ }^{5}$, Dashnamoorthy Ravi² and Andrew M. Evens ${ }^{2}$

${ }^{1}$ Cancer Research Center, Hampton University, Hampton, VA, USA

2 Division of Blood Disorders, Rutgers Cancer Institute of New Jersey, New Brunswick, NJ, USA

${ }^{3}$ WYLE, NASA Ames Research Center, Moffett Field, CA, USA

${ }^{4}$ Division of Pathology, Tufts Medical Center, Boston, MA, USA

${ }^{5}$ Cummings School of Veterinary Medicine, Tufts University, Boston, MA, USA

* These authors contributed equally to this work

Published: September 07, 2018

Copyright: McDonald et al. This is an open-access article distributed under the terms of the Creative Commons Attribution License 3.0 (CC BY 3.0), which permits unrestricted use, distribution, and reproduction in any medium, provided the original author and source are credited.

This article has been corrected: The correct author name is given below:

\section{Cheryl A. London}

Original article: Oncotarget. 2018; 9:22693-22702. https://doi.org/10.18632/oncotarget.25209 